\title{
РОДИНА НІКІТІНИХ В ІСТОРІЇ СТАНОВЛЕННЯ ПОДВИЖНИЦЬКОГО РУХУ УКРАЇНИ У ПЕРШЙ ПОЛОВИНІ ХХ СТ.
}

\author{
Присвячується пам'sті науковия, \\ педагога, краєзнавия та журналіста С.І. Шевченка
}

\begin{abstract}
Анотація: Аналізується громадська, просвітницька та культурницька діяльність членів родини Нікітіних. Особливу увагу в статті приділено подвижницьким зусиллям у сфері національно-культурного пробудження місцевого населення Украӥни, зокрема, в Елисаветграді (тепер Кропивницький) у першій половині ХХ ст. - Василя Нікітіна. В. Нікітін співпращював 3 такими видатними представниками української інтелігенції того періоду як М. Кропивницький, М. Садовський, М. Заньковецька, Ю. Тобілевич, П. Саксаганський, М. Левитський, П. Михалевич, С. Єфремов тощо. Діти В. Нікітіна - Ф.Нікітін, Ю. Нікітін і Т. Нікітіна-Станіславська, які виховувалися у дусі любові до Украӥни, також стали на шлях проукраӥнської подвижницької діяльності. Автор констатує, що родина Нікітіних відіграла вагому роль у подвижницькому русі України першої половини XX ст. та займає визначне місие у патріотичній боротьбі за українську державність.
\end{abstract}

Ключові слова: родина Нікітіних, подвижницький рух, Україна, Єлисаветград

В історичній парадигмі становлення та розвитку українського подвижницького руху України кінця XIX - першої половини XX ст. визначним явищем були родинні його прояви, які, на нашу думку, відіграли роль одного з фундаментальних чинників в утвердженні українства як такого, у всіх його проявах. Унікальність цих родин полягала у тому, що вони становили собою кровне однодумство за світосприйняттям у поглядах на українство, й становили собою ядро духовно-творчого пориву української нації. До когорти таких визначних українських родин, для яких любов до України та українського народу не були пустим дзвоном, безумовно, слід віднести й родину юриста та педагога з Єлисаветградщини Василя Олександровича Нікітіна.

Дослідженню громадської, просвітницької та культурницької діяльності членів родини Нікітіних на сьогоднішній день присвячена досить невелика кількість наукових розвідок, статей, публікацій С. Шевченка ${ }^{1}$, В. Босько ${ }^{2}$, В. Степанова ${ }^{3}$ тощо. Найбілыш

\footnotetext{
"Печериия Тетяна Вікторівна - кандидат історичних наук, доцент кафедри мовних та гуманітарних дисциплін № 2 Донецького національного медичного університету (м. Кропивницький, Україна);

ORCID: https://orcid.org/0000-0001-6919-1974; e-mail: Pecheritca18@gmail.com

${ }^{1}$ Шевченко С. Василь Нікітін - організатор українського життя в Єлисаветграді // Наукові записки КДПУ. Серія: історичні науки. Кіровоград, 2011. Вип. 14. С. 294-302.

${ }^{2}$ Босько В. Кролики для диктатури пролетаріату, або Єлисаветградський Фауст у місцевій катівні // Історичний календар Кіровоградщини на 2009 р. Кіровоград, 2008. С. 24-28.

${ }^{3}$ Степанов В. В. Нікітін - жертва сталінського терору // Кіровоградщина на зламі тисячоліть: стан, проблеми,
} 
грунтовною є наукова публікація підготовлена С. Шевченком, в якій автор особливу увагу приділив подвижницькій діяльності В.Нікітіна. У статті В.Степанова подано досить обмежене коло інформації про В.Нікітіна, найбілыше уваги приділено періоду його переслідування й арешту. Щодо висвітлення життя та діяльності одного із синів В. Нікітіна - Ф. Нікітіна, то на увагу заслуговує публікація В. Боська, в якій він, зокрема, докладно аналізує життєвий шлях і здобутки Ф. Нікітіна у сфері кролівництва. Вважаємо, що той обсяг досліджень присвячених родині Нікітіних, який був зроблений науковцями до цього часу, не є грунтовним і завершеним, а тому питання потребує подальшого вивчення та висвітлення.

Метою даного дослідження є спроба проаналізувати подвижницькі зусилля членів родини Нікітіних у громадській, просвітницькі та культурницькій сферах, а також визначити місце й роль цієї родини у становленні та розвитку подвижницького руху України першої половини XX ст., й тим самим, привернути увагу до родини Нікітіних не лише науковців, а й у цілому української громади.

Проведений нами грунтовний аналіз життєдіяльності родини Нікітіних у всій їі багатогранності дозволяє стверджувати, що цементуючим початком у формуванні проукраїнського світогляду усіх членів родини Нікітіних, безперечно, був ії голова Василь Олександрович Нікітін (1868-1942). Сам В. Нікітін був родом з Полтави, де він народився у 1868 р. в сім'ї службовців середнього достатку. Відомо, що його батько за національністю був росіянином, а мати українкою.

У 1881 р. після смерті матері, його батько, який важко сприйняв смерть дружини, вирішив залишити м. Полтаву й переїхав до м. Вязьми Смоленської губернії. У зв'язку з цим, освіту В.Нікітін здобував спочатку у В'яземській гімназії, а пізніше на юридичному факультеті Московського університету. Після закінчення університету у 1891 р. В. Нікітін став кандидатом на суддівську посаду та служив у таких містах як Смоленськ, Дорогобуж, Вязьма, пізніше зайняв посаду міського судді м. Гжатська Смоленської губернії, на якій він пропрацював аж до 1903 р.

Аналізуючи епістолярні спогади про В.Нікітіна його сина Фауста, стає цілком зрозумілим наскільки сильно він сумував за Україною. Так, у листі від 21 червня 1970 р. Ф. Нікітіна до М. Смоленчука, в якому він описує основні біографічні віхи життя свого батька, він, зокрема, зазначав: «Скільки його пам'ятаю, він весь час захоплювався природою України і Т. Шевченком. Літні канікули ми тоді проводили на Україні» ${ }^{4}$. Отже, із спогадів залишених його сином Фаустом стає зрозуміло, що незважаючи на те, що терени України В. Нікітін, за роком долі, залишив ще у 12-річному віці, пам'ять про співочий український народ і прекрасні українські краєвиди завжди жила у його серці та душі.

У зв'язку з вищезазначеним, маємо підстави вважати, що своє звільнення у 1903 р. 3 посади міського судді м. Гжатська та переведення його до м. Єлисаветграда членом окружного суду, В. Нікітін сприйняв як подарунок долі, який дозволив йому повернутися на батьківщину. Саме з 1903 р. розпочинається активна подвижницька діяльність В. Нікітіна, яка була спрямована на національно-культурне пробудження місцевого населення України, зокрема, в Єлисаветграді (нині м. Кропивницький). Родина Нікітіних, й власне 
їхній будинок на розі вулиць В. Перспективної та Н. Донської (нині Тараса Карпи), стають одним із осередків українського подвижницького руху Єлисаветграда.

Зокрема, відомо, що по четвергах В. Нікітін організовував у себе літературно-музичні зустрічі (так звані журфікси), на яких збиралася українська інтелігенція міста і на яких окрім музикування обговорювалося українське питання. Із опрацьованих нами джерел відомо, що серед відвідувачів журфіксів які організовував В.Нікітін були донька композитора М. Лисенка - Галина Миколаївна 3 чоловіком (К.Шило) Г. Нейгауз, М. Заньковецька, М. Кропивницький, П. Саксаганський, Ю. Тобілевич, Ю. Мейтус тощо. Окрім того, нерідко у В. Нікітіна збиралася молодь з гімназій і робітники заводу «Ельворті» для обговорення національної проблематики ${ }^{5}$.

Слід зазначити, що саме В. Нікітін, як правило, був ініціатором та організатором нових форм організації шляхів популяризації й утвердження серед населення проукраїнської позиції в життя. Так, саме В. Нікітін запропонував місцевій українській інтелігенції, яка збиралася у нього на журфікси, щорічне проведення в Єлисаветграді Шевченківських вечорів у міському театрі (нині Кропивницький академічний обласний український музично-драматичний театр імені М.Л. Кропивницького). На жаль, Шевченківські вечори в Єлисаветграді вдалося провести лише двічі у 1909 р. і 1910 р., після чого їх проведення було заборонено губернатором.

у своїх спогадах про батька, Ф. Нікітін частково описав як саме, за яким сценарієм, проходили ці вечори: «Вечори ці відкривалися лекцією Василя Олександровича про життя і творчість Т.Г. Шевченка, після чого хор на сцені співав «Як умру, то поховайте» («Заповіт» Т.Г.Шевченка), а потім був концерт силами провідних українських артистів» ${ }^{6}$. Із опрацьованих нами джерел також відомо, що на другому, останньому Шевченківському вечорі виступив і батько українського театру М. Кропивницький. Всю організаційну частину роботи по влаштуванню Шевченківських вечорів виконував В. Нікітін. Результатом проведення 6 березня 1910 р. другого Шевченківського вечора став прибуток у сумі 380 руб. 41 коп., який було відправлено від полтавської земської управи для зарахування до фонду на спорудження пам'ятника Т.Г Шевченку у Києві за квитанцією єлисаветградської контори № 417. Цікавим є й той факт, що із цих 380 руб. 41 коп. - 50 руб. 80 коп. становили пожертви (благодійні внески), які зробили містяни ${ }^{7}$

3 часом жандармерія все ж таки довідалася про провідну роль у цих заходах В. Нікітіна, у зв'язку з чим, йому було запропоновано або негайно припинити подібну діяльність, або ж піти з державної служби. В. Нікітін обрав друге - він пішов у відставку й перейшов на напівприватну роботу нотаріусом.

У контексті усього вище зазначеного, хотілося б акцентувати увагу на відносинах які склалися у В. Нікітіна з М. Кропивницьким. Для початку зазначимо, що як відомо із спогадів самого В. Нікітіна, творчістю театру М. Кропивницького він захоплювався ще зі студентських років, й неодноразово, зокрема, й у 1887 р. відвідував вистави славетної

\footnotetext{
${ }^{5}$ Кіровоградський обласний краєзнавчий музей (далі - КОКМ). КОМ Інв. № AI - 6564.

${ }^{6}$ B ім'я України: Василь Нікітін: листи, статті, спогади / уклад. С. Шевченко, Т. Печериця. Кіровоград, 2011. C. $44-45$.

${ }^{7}$ Звіт із влаштування українського концерту - вечора пам'яті Т.Г. Шевченка 16.III.1910 р. // Голос Юга. 1910. 5 июня.
} 
української трупи, коли та приїздила до Москви. Зі спогадів Ф. Нікітіна відомо, що М. Кропивницький декілька разів гостював у них дома в Єлисаветграді. 3 ним В. Нікітін вів розмови про культурний український рух і про заходи в умовах царського режиму. Особливо жвавим було спілкування В. Нікітіна з М. Кропивницьким у 1910 р. 3 їхньої переписки до наших днів збереглося декілька листів від М. Кропивницького до В. Нікітіна, із звернень у листах до В. Нікітіна «Високоповажний (вельмишановний) добродію Василь Олександровичу!», «Щиро шануючий Вас М. Кропивницький», а також зі змісту цих листів стає зрозуміло, що їхнє знайомство поступово переросло у справжню та щиру дружбу ${ }^{8}$.

у подальшому посилення репресій i початок Першої світової війни дещо загальмували та послабили український рух. В цей період часу В.Нікітін потрапив у жандармські списки політично неблагонадійних, де він фігурував як «український соціаліст». Всі ці обставини змусили В. Нікітіна дещо інактивувати свою проукраїнську діяльність і навіть переховуватися від поліції. Лише після революційних подій у лютому 1917 р. відбулося поступове відновлення сприятливих умов для подальшого розвитку проукраїнського подвижницького руху. Щоб бути якомога ближче до молоді, робітників і, в цілому, до українського народу, В.Нікітін вирішує розпочати свою діяльність на педагогічній ниві - він стає лектором української мови та літератури, спочатку на громадських засадах, а вже пізніше розпочинає свою офіційну викладацьку діяльність у школах і технікумах. Окрім того, у цей період часу В. Нікітін організовує й очолює «Просвіту», при якій почали працювати бібліотека та хор 9.

Зроблений нами аналіз навіть однієї лекції В.Нікітіна від 29 квітня 1918 р., інформація про зміст якої дійшла до нашого часу, свідчить про його глибокий та усвідомлений патріотизм до України Він не лише високо цінував, але й пишався здобутками української народу в культурній сфері та захоплювався її найкращими творцями. Лекція «Про українську культуру» була прочитана В. Нікітіним у неділю 29 квітня 1918 р. в залі «Просвіти», що знаходилася по вул. Петрівській (нині Т.Г. Шевченка). Аудиторія, яка прийшла послухати лекцію, становила приблизно 50 осіб, а сама лекція тривала біля години. Зокрема, розповідаючи про розвиток української літератури, В. Нікітін найвищу оцінку дає Т.Г. Шевченку, якого називає «величнішим із світових геніїв», ставить його як поета вище Пушкіна та Міцкевича: «...Шевченко був ближчим до народу» ${ }^{10}$.

На початку 20-х рр. ХХ ст., у зв'язку з голодом, В. Нікітін змушений був виїхав 3 Єлисаветграда до с. Добровеличківка Первомайської округи. Вже у 1923 р. В. Нікітін повернувся до Єлисаветграда, де знову з головою поринув у громадську та просвітницьку діяльність, у ході якої реалізовував політику українізації в життя. Зокрема, у цей період часу він бере участь в організації краєзнавчого гуртка при історичному музеї, а також пише історію українського театру на Єлисаветградщині. Саме праця над цією роботою звела його у 1928 р. $з$ академіком ВУАН С. Єфремовим і професором П. Руліним. 4 жовтня 1929 р. В. Нікітін був заарештований Зінов'євським окружним відділом ДПУ за підозрою у

\footnotetext{
8 ДАКО. Ф. Р-6976. Оп. 1. Спр. 60. Арк. 7.

${ }^{9}$ Шевченко С. Перший голова міської «Просвіти» // Лицарі українського степу: Збірка статей (1983-2008рр.) Кіровоград, 2008. С. 269-270.

${ }^{10}$ В ім'я України: Василь Нікітін: листи, статті, спогади / уклад. С. Шевченко, Т. Печериця. Кіровоград, 2011. C. 27-28.
} 
нелегальних зв'язках 3 українськими шовіністичними елементами 3 інтелігенції та групуванні їх з контрреволюційною метою. Зі звинуваченням в українській діяльності та тавром «ворога народу» В. Нікітін був висланий, згідно 3 постановою особливої трійки при колегії ДПУ УСРР від 26 січня 1930 р. за ст. 54-10 КК УСРР (антирадянська агітація у галузі освіти) на три роки до Казахстану ${ }^{11}$. Після закінчення терміну ув'язнення, й аж до самої смерті у червні 1942 р. від голоду, В.Нікітін так і не отримав права жити в Україні. Реабілітовано В. Нікітіна було через 52 роки після смерті у 1994 p. ${ }^{12}$

Реальний приклад батька виховував і надихав дітей В. Нікітіна, які прагнули зробити свій вклад у подвижницьку боротьбу українського народу. Зазначимо, що у В. Нікітіна було два сина - Фауст та Юрій і три доньки - Тетяна, Ніна, Марія. Найстаршим у сімї̈ був син Фауст, який народився 20 липня 1894 р. у м. Гжатську Смоленської губернії. У період 19031913 рр. він навчався в Єлисаветградській чоловічій гімназії. Із спогадів залишених Ф. Нікітіним, відомо, що під час навчання у гімназії він товаришував з М. Чеботарьовим, Б. Завадовським та І. Таммом. Найбілыш дружні стосунки у Ф. Нікітіна склалися 3 I. Таммом, що було обумовлено проживанням поруч сімей В. Нікітіна й $Є$. Тамма ${ }^{13}$. Ця гімназійська дружба зберігалася ними більш ніж тридџять років. Перебуваючи у другій половині 1930-х рр. у відрядженні в Москві, Ф. Нікітін відвідав Б. Завадовського і вже разом 3 ним вони пішли у гості до Гори Тамма, який, як виявилося, проживав неподалік ${ }^{14}$.

Вищу освіту $\Phi$.Нікітін здобував на фізико-математичному факультеті у Московському університеті, куди вступив у 1913 р. На жаль, навчання в університеті він змушений був залишити у зв'язку 3 початком Першої світової війни, змінивши університетську освіту на військову - вступивши восени 1914 р. до Одеського військового училища. Після навчання з 1915 р. почав служити у звані прапорщика в 32-му запасному батальйоні. У червні 1915 р. потрапив на фронт, командував ротою в 13-му Білозерському полку під Львовом. У боях він був двічі тяжко поранений і контужений. У цілому за участь у бойових діях під час Першої світової війни Ф. Нікітін був нагороджений п'ятьма бойовими нагородами, серед яких був й орден Георгія Побідоносця 4-го ступеня. У грудні 1917 р. Ф. Нікітін повернувся з фронту додому й невдовзі був знятий з військового обліку, у зв'язку 3 тяжкою контузією, яку він отримав під час війни.

Щодо особистого життя Ф. Нікітіна відомо, що він мав дружину та сина, однак, на жаль, у травні 1920 р. його перша дружина померла від сухот. У 1920-1922 рр. Ф. Нікітін навчався на зоотехнічному відділенні в Єлисаветградському агрономічному політехнікумі. Певний період часу, а саме з 1922 р. по 1925 р., він працював учителем математики, пізніше був службовцем. Ф.Нікітін доклав чимало зусиль до створення в Єлисаветграді природничо-історичного музею, а у 1927-1930 рр. очолював Зінов'ївське окружне наукове краєзнавче товариство. Із спогадів залишених Ф. Нікітіним, також відомо, що саме за його сприянням, влітку 1924 р. чи то 1925 р., отримав рекомендацію до консерваторії та був

\footnotetext{
${ }^{11}$ Степанов В. В. Нікітін - жертва сталінського терору // Кіровоградщина на зламі тисячоліть: стан, проблеми, перспективи. Кіровоград, 1999. С. 85-87.

${ }^{12}$ Печериия T. В. Нікітін - визначний подвижник України кінця XIX - першої половини XX ст. // Гілея: науковий вісник. 2019. Вип. 144 (№ 5). Ч. 1. Історичні науки. С. 95.

${ }^{13}$ КОКМ. КОМ Інв. № AI - 6564.

${ }^{14}$ Воспоминания о И.Е. Тамме. Москва, 1986. С. 179-180.
} 
відправлений на навчання до Одеської консерваторії, надзвичайно музично обдарований робітник слюсар збірного цеху заводу «Червона зірка» Михайло Гришко. Окрім того, відомо, що саме Ф. Нікітін наприкінці 1920-х рр. виявив на старому Биківському цвинтарі поховання матері й сестри І. Карпенка-Карого, які після цього були перенесені до хутора Надія ${ }^{15}$.

Окрім активної проукраїнської громадської діяльності Ф. Нікітін займався на науковому рівні кролівництвом, це захоплення поступово переросло у сенс його наукових зоотехнічних пошуків усього життя. У 1930 р. Ф. Нікітін видав в Єлисаветграді свою першу наукову працю українською мовою «Практичне кролівництво».

Під час розгулу радянських репресій у 30-х рр. ХХ ст. серед працівників різних галузей науки, за підозрою участі в антирадянській організації, у жовтні 1930 р. було заарештовано й Ф. Нікітіна. Умови утримання ув'язнених були суворими. Із спогадів $Ф$. Нікітіна нам відомо про методи тортур, які тоді застосовували до заарештованих. Найбільш поширеною була так звана «статуя», яку було застосовано і по відношенню до Ф. Нікітіна, після того як він категорично відмовився писати наклеп на себе й інших. Суть цього знущання полягала у постійному стоянні на одному місці, у результаті в людини спочатку набрякали ноги, потім тулуб і руки, обличчя, наслідком такого неприродного процесу була водянка, яка призводила до смерті у страшних муках ${ }^{16}$.

У кінці кінців, так і не отримавши від Ф. Нікітіна ніякого зізнання в антирадянській діяльності, у 1931 р. його разом 3 іншими старими інтелігентами міста вислали 3 Єлисаветграда. Під час перебування у Харкові на пересильному пункті, Ф. Нікітіну було повідомлено, що його направляють для роботи за спеціальністю (кролівництво) у радгосп Темніковського табору НКВС №3 у Мордовській АРCP $^{17}$. у цьому таборі Ф. Нікітін змушений був пропрацювати зоотехніком по кролівництву протягом 1931-1935 рр. й за перевиконання плану по кролівництву навіть отримав грамоту передовика. У період 19351940 рр. Ф. Нікітін працював на посаді наукового співробітника Воронезького опорного пункту НВI кролівництва, де йому вдалося вивести нову породу кроликів-рексів. У 1941 р. під час евакуації переїхав працювати до Бірюлінського звірорадгоспу Татарстану. Результатом його наукових зоотехнічних розробок стало виведення ще двох нових порід кроликів - чорно-бурої та вуалево-сріблястої, за що він у 1951 р. отримав Державну премію СРСР. Повна реабілітація Ф. Нікітіна відбулася у 1956 р.

Після виходу на пенсію у 1957 р. Ф. Нікітін проживав у Казані, Смоленську, а в 19621981 pp. - у Чернівцях. Ф. Нікітін є автором 35 книг і брошур та 200 статей, що були опубліковані у журналах і газетах українською, російською й татарською мовами. Після смерті дружини у 1981 р., Ф. Нікітін переїхав доживати віка у селище Бірюлінського звірорадгоспу ТатРСР. Помер видатний генетик 16 жовтня 1992 p. ${ }^{18}$

Не менш важливий внесок до українського подвижницького руху 20-30-х рр. XX ст.

\footnotetext{
${ }^{15}$ KOКМ. КОМ Інв. № AI - 6564.

${ }^{16}$ Босько В. Кролики для диктатури пролетаріату, або Єлисаветградський Фауст у місцевій катівні // Історичний календар Кіровоградщини на 2009 р. Кіровоград, 2008. С. 24-28.

${ }^{17}$ КОКМ. КОМ Інв. № AI - 9650. С. 13.

${ }^{18}$ Бонфельд С. Фауст Нікітін. Шляхетно - впродовж довгого життя // Єлисаветградська гімназія. Кн. 1. Кіровоград, 1997. С. 114-115.
} 
зробив і менший син В. Нікітіна - Юрій. Ю. Нікітін народився в Єлисаветграді Херсонської губернії 4 січня 1905 р. Відомо, що навчався він в Єлисаветградській чоловічій гімназії М. Крижановського, де у нього склалися дружні стосунки 3 А. Тарковським, М. Станіславським, Андрієм і Назаром Тобілевичами. У спогадах Т. Нікітіної-Станіславської про брата Юрія та його єлисаветградське оточення вона зазначила: «Зранку до вечора вони читали, декламували різні вірші - свої (відомо, що Ю. Нікітін писав вірші), Гумільова, Блока, Маяковського, Байрона та Пушкіна... Натхненно читав Ю. Нікітін і вірші П. Тичини...» ${ }^{19}$.

У 1928 р. Ю. Нікітін закінчив музично-драматичний інститут імені М. Лисенка, після чого отримав запрошення працювати у знаменитому театрі «Березіль». Відомо, що Ю. Нікітін, працюючи у театрі «Березіль», паралельно ще й працював над власним проектом - мріяв організувати у Харкові свій український драматичний театр. У 19321935 рр. працював викладачем у Київському театральному інституті, де викладав сценічну мову. В цілому, становлення Ю.Нікітіна як актора та режисера відбувалося під керівництвом таких титанів мистецтва України як Лесь Курбас, а пізніше ще й Олександр Довженко. До режисерської лабораторії останнього Ю. Нікітін вступив у 1935 р. і саме навчання у режисерській лабораторії дозволило Ю. Нікітіну в подальшому залишитися працювати на Київській кіностудії.

На жаль, життя і творчий потенціал талановитого актора та режисера Ю. Нікітіна, як і багатьох інших відомих митців України 30-40-х рр. ХХ ст., були безжально зруйновані радянською карально-репресивною владою. 4 січня 1938 р. Ю. Нікітіна було заарештовано за підозрою у шпигунстві на користь Німеччини, і хоча винним себе він не визнав, отримав п’ять років ув'язнення у Північно-Східному таборі Магаданської області. У жахливих умовах табору Ю. Нікітін зміг протриматися лише два 3 половиною роки й у 1940 р., у віці 35-ти років, помер від сухот і недокрів'я. Сіроокий красень і талановитий читець-декламатор загинув у розквіті літ... ${ }^{20}$.

Досить відомою у театральних колах України було й ім'я найменшої дочки В. Нікітіна - Тетяни Василівни Нікітіної-Станіславської. Т. Нікітіна народилася в Єлисаветграді у 1907 p., навчалася в Єлисаветградській жіночій гімназії та приватній гімназії 0. Єфимовської ${ }^{21}$. Зростала Тетяна, як і їі брат Юрій, в оточенні дітей українських митців, серед їі друзів були М. Станіславський (який пізніше став ії чоловіком), Андрій і Назар Тобілевичі, А. Тарковський. Подальшу освіту здобувала у Державному музичнодраматичному інституті імені М. Лисенка, під час навчання отримала запрошення у театр «Березіль» Л. Курбаса, який переїхав до Харкова.

У 1928 р., у зв'язку із запрошенням, Т. Нікітіна-Станісавська змушена була переїхала до Харкова, де продовжила навчання у Харківському державному музично-драматичному інституті. Там вона, разом зі своїм чоловіком М. Станіславським, грала у виробничому театрі «Молодар» (Молоді артисти революції) під керівництвом Гната Ігнатовича. Відомо,

\footnotetext{
${ }^{19}$ Я жил и пел когда-то...». Воспоминания о поете Арсении Тарковском. Томск, 1999. С. 5-8.

${ }^{20}$ В ім'я України: Василь Нікітін: листи, статті, спогади / Уклад.: С. Шевченко, Т. Печериця. Кіровоград, 2011. C. 8.

${ }^{21}$ Шевченко С. Старі стіни: Єлисаветградська громадська жіноча гімназія (1860-1920 рр.). Кіровоград, 2007. C. 132.
} 
що у післявоєнний період Т. Нікітіна-Станіславська доклала чимало зусиль для відродження театру ляльок у Житомирі в 1945 р. i, зокрема, стала його першим режисером, та в Івано-Франківську. Більшу частину свого життя Т. Нікітіна-Станіславська, разом із чоловіком, прожила у Житомирі, де працювала викладачем спочатку у Житомирському педагогічному інституті імені I. Франка, а пізніше у Житомирському культпросвітучилищі. Померла українська театральна актриса, режисер, педагог, заслужена артистка УРСР у 1991 p. $^{22}$

Окрім Тетяни, у В. Нікітіна було ще дві доньки - Ніна (1899 р.н.) та Марія (1901 р.н.). На жаль, про їхнє життя нам відомо вкрай мало. Відомо лише, що М. Нікітіна закінчила Єлисаветградську громадську гімназію й учителювала у Любомирці, а пізніше, після заміжжя (iї чоловіком став О.Филимонов, який був родом із Добровеличківки), у Добровеличківці Первомайської округи. Щодо Н. Нікітіної відомо лише те, що освіту вона отримала у гімназії О. Єфимовської, після чого викладала у Залізничній школі² .

Таким чином, здійснений грунтовний аналіз громадської, просвітницької та культурницької діяльності членів родини Нікітіних, зокрема, В. Нікітіна, Ф. Нікітіна, Ю. Нікітіна та Т. Нікітіної-Станіславської дозволяє нам стверджувати, що всі зусилля родини були спрямовані на утвердження національної ідеї в українському суспільстві, відродження української мови та духовності. Ми можемо констатувати, що родина Нікітіних відіграла вагому роль у проукраїнському подвижницькому русі України першої половини XXст. та займає визначне місце у патріотичній боротьбі за українську державність.

\section{Tetyana Pecherytsia}

\section{The Nikitin's family in the history of the formation of the ascetic movement of Ukraine} in the first half of the $\mathrm{XX}$ century

Abstract: The article analyzes social, educational and cultural activities of the Nikitin's family members. The article pays special attention to ascetic efforts in the field of national and cultural awakening of the local population of Ukraine, in particular, in the city of Yelisavetgrad (now Kropivnitsky) first half of the XX century V. Nikitina. V. Nikitin collaborated with such prominent representatives of the Ukrainian intelligentsia of that period as M. Kropyvnytsky, M. Sadovsky, M. Zankovetska, Y. Tobilevych, P. Saksagansky, M. Levitsky, P. Mykhalevych, S. Yefremov and others. Especially friendly relations in V. Nikitna formed with M. Kropyvnytsky, who repeatedly visited V. Nikitin while in Yelisavetgrad. V. Nikitin was a staunch patriot of Ukraine, for which in 1930 he arrested and sentenced to three years.

V. Nikitin's children - F. Nikitin, Yu. Nikitin and T. Nikitina-Stanislavskaya, which all in

\footnotetext{
${ }^{22}$ Єлисаветградське коло Арсенія (Закінчення) URL: http://poet.inf.ua/krasne-pismenstvo/yelisavetgradske-koloarseniya-tarkovskogo-4/

${ }^{23}$ В ім'я України: Василь Нікітін: листи, статті, спогади... С. 9.
} 
the spirit of love for Ukraine, also embarked on the path of ascetic activity. For his proUkrainian public activities, F. Nikitin in 1930 and Yu. Nikitin in 1938 arrested and sent to camps. Unfortunately, Yu. Nikitin did not endure the inhumane conditions of the NorthEastern camp of the Magadan region and died in 1940 at the age of 35.

The author states that the Nikitin's family played an important role in the ascetic movement of Ukraine in the first half of the XX century and occupies a prominent place in the patriotic struggle for Ukrainian statehood.

Keywords: Nikitin's family, ascetic movement, Ukraine, Yelisavetgrad 